items follows. Many of the latter seem more pertinent to the subject matter of the book, and more necessary to qualify and summarize because they are less familiar to the average librarian.

As a brief, introductory volume to certain of the problems encountered in the education of librarians, this text will no doubt serve a useful role. One might quarrel with the title, since there are other major problems which have not been included. For instance, are there no difficulties in the training of reference librarians, catalogers and administrators? In a second edition the present title might be amended so as to suggest more clearly the trend of the contents.-Harriet D. MacPherson, Drexel Institute of Technology.

\section{Rare Bibles}

Rare Bibles; an Introduction for Collectors and a Descriptive Checklist. By Edwin A. R. Rumball-Petre. New York, Philip C. Duschnes, 1954. 53 p. $\$ 6.00$.

This is a revised edition of the work of the same title issued in 1938. Its compiler, the late Rev. Rumball-Petre, who died in July, I954, is said to have been the only bookman who dealt exclusively with rare editions of the Bible.

In scope and arrangement the two editions are similar, beginning with "Incunabula," continuing with "Polyglots," "English Bibles," "Bibles Printed in America," "Hebrew, Greek and Latin Bibles," and "Bibles in Modern Languages other than English." The sections for "Miscellaneous Bible Portions" and "Curious Editions of the Bible" cut across the other categories both in time and language.

There are 378 items listed as against 345 in the first edition, the incunabula section, increased from twenty to forty items, being responsible for the greatest number of additions. Aside from this, the main difference between the two editions is in the character of the notes. In the first edition there were occasional references to prices but these have been omitted in the revision and the descriptions are limited to bibliographical and historical data.

Revision barely touched the bibliography. Only a half-dozen additions appear and one of these was published in 1838 . It seems strange that it was added while such a worth- while aid to the modern collector as the Pierpont Morgan Library's catalog of their exhibition of Bibles in 1947 was not included. The number of volumes of the Gesamtkatalog has not been brought up to date nor were later editions of works mentioned that have been brought out in new editions since 1938 .

The compiler made it clear that the basis for his selection was rarity coupled with some historic or distinctive feature. But for some unexplained reason he did not include a single one of the Bibles famous because of their illustrations, for example, the Cologne Bible, the Lübeck Bible or the Malermi Bible. Among famous modern editions Bruce Roger's Lectern Bible is listed but not his World Bible. However it is individual taste that makes collectorship interesting and this is a useful handbook for a collector or historian of printing.

The two editions are witnesses of the change in book production during these last two decades. The 1938 publication of 500 copies reflects the fine printing of the day in the quality of the paper, the generous margins, and the eight illustrations which enliven the text. The 1954 edition of 600 copies has a slightly longer text compressed into ten less pages by crowding more words on a page of less attractive paper; there are no illustrations and the price is exactly double that of the 1938 edition.-Bertha M. Frick, School of Library Service, Columbia University.

\section{Book Collectors}

\section{Private Book Collectors in the United States and Canada. Ioth rev. ed. New York,} R. R. Bowker, 1953. 4I7 p. \$20.00.

The importance of the private book collector to librarians and to the future of the libraries under their care is something too clearly evident and, indeed, too widely recognized to require either persuasive argument or elaborate demonstration.

One has but to reflect upon some of the names which adorn the façades and which are found engraved upon the bookplates of libraries large and small all across the land to realize that the private collector has in the past played, and in an increasingly prominent manner continues to play, a vital rôle in the development and enrichment of American libraries. 